\title{
"Alperujo" Compost Improves the Ascorbate (Vitamin C) Content in Pepper (Capsicum annuum L.) Fruits and Influences Their Oxidative Metabolism
}

\author{
Germán Tortosa ${ }^{1, *(1)}$, Salvador González-Gordo ${ }^{2}$ () , Carmelo Ruiz $^{2}$, Eulogio J. Bedmar ${ }^{1}$ (1) and \\ José M. Palma 2 ii \\ 1 Department of Soil Microbiology and Symbiotic Systems, Estación Experimental del Zaidín, CSIC, \\ Profesor Albareda, 1, 18008 Granada, Spain; eulogio.bedmar@eez.csic.es \\ 2 Group of Antioxidants, Free Radicals and Nitric Oxide in Biotechnology, Food and Agriculture (ARNOBA), \\ Department of Biochemistry, Cell and Molecular Biology of Plants, Estación Experimental del Zaidín, CSIC, \\ Profesor Albareda, 1, 18008 Granada, Spain; salvador.gonzalez@eez.csic.es (S.G.-G.); \\ carmelo.ruiz@eez.csic.es (C.R.); josemanuel.palma@eez.csic.es (J.M.P.) \\ * Correspondence: german.tortosa@eez.csic.es; Tel.: +34-958-181-600
}

Received: 19 April 2018; Accepted: 23 May 2018; Published: 25 May 2018

\begin{abstract}
Alperujo" compost was evaluated as an organic fertiliser for pepper growth under greenhouse conditions. Even though the total nitrogen applied was similar, plants only grown with composts experienced a development decline as compared to those grown with standard nutrient solution. This was perhaps because nitrogen from the compost was essentially organic, and not easily available for roots. When, alternatively, the compost was supplemented with nitrate, a synergetic effect was observed, favouring plant development and fruit yield, simultaneously with the increase of compost rates. Compost affected the oxidative metabolism of pepper plants by increasing their antioxidative enzyme activities catalase and superoxide dismutases and the non-enzymatic antioxidants ascorbate and glutathione. Overall, when nitrogen limitation occurred and only compost was used as fertiliser, an oxidative stress took place, whereas in plants grown with nitrate-supplemented compost it did not. Furthermore, these pepper plants experienced a yield increase and, more importantly, an enhancement of the ascorbate content.
\end{abstract}

Keywords: antioxidants; ascorbic acid; organic fertiliser; reactive oxygen species; nitrogen availability; greenhouse experiment

\section{Introduction}

Mineral or inorganic fertilisers are widely used in agriculture. Inorganic fertilisers are applied to soils under their easily assimilable forms, providing the principal nutrients to crops [1]. During the last 50 years, inorganic fertilisers have increased agricultural yield and productivity globally. In fact, the global fertiliser nutrient $\left(\mathrm{N}+\mathrm{P}_{2} \mathrm{O}_{5}+\mathrm{K}_{2} \mathrm{O}\right)$ consumption is still increasing [2]. However, inorganic fertiliser doses are commonly overestimated and can produce environmental pollution. For instance, several authors and reports have shown that an excess in the application of nitrogen-based fertilisers can generate contamination in soils, surface and groundwater, and also in the air by releasing greenhouse gases which contribute to global warming [3-6].

Nowadays, soil protection is considered as one of the main concerns in agricultural policies since unpolluted soils are directly correlated to food production and security [7]. To achieve this purpose, increasing the organic matter content in agricultural soils could be a reliable strategy, as the organic matter losses are directly related to soil fertility [8]. Agriculture and the agro-food industry yearly generate an important amount of organic wastes that can be used for obtaining soil fertilisers and 
amendments by biological treatments such as anaerobic digestion or composting. An example of that can be found in the two-phase olive mill waste (popularly called either "alperujo" or "alperoujo" (AL)), the main organic waste generated by the Spanish olive oil industry [9]. It has been demonstrated that composting is a feasible and low-cost technology for its treatment [10] as well as for producing commercial organic amendments and fertilisers with humic characteristics [11,12]. Composts have been extensively used in agriculture, especially under organic farming. Organic matter from composts positively affect physical, chemical and biological properties of soils, as well as the physiological development of plants [13].

Although they are indigenous to South and Central America and the West Indies, pepper (Capsicum annuum L.) is nowadays one of the most consumed vegetables worldwide due to its dietary, culinary and gastronomic versatility [14]. There are more than one hundred pepper varieties according to their degree of pungency (sweet, mild or hot) and their shapes, colour at ripening and sizes. Chilli and sweet peppers are cultivated globally. China, Mexico, Turkey, Indonesia and Spain are the main producing countries, representing in 2014 49.9\%, 8.5\%, 6.6\%, 5.8\% and 3.5\% of world pepper tonnage, respectively [15]. Pepper crops consume an important amount of mineral fertilisers and, therefore, composts would be ideal to reduce the application of fertilisers without compromising yield productivity [16-18].

The feasibility and effectiveness of composts as organic fertilisers and their effect on physiological development can be analysed by studying the oxidative metabolism development of proper plant profiles, which is commonly used as a metabolic indicator of the cell/organism status $[19,20]$. Under low concentrations, reactive oxygen species (ROS) such as superoxide radical $\left(\mathrm{O}_{2}{ }^{-*}\right)$ and hydrogen peroxide $\left(\mathrm{H}_{2} \mathrm{O}_{2}\right)$ are essential for signalling processes which are involved in plant growth and development, in the response and adaptation to environmental conditions, and in programmed cell death, among others. By contrast, ROS under high concentrations can produce oxidative stress which strongly affects cell metabolism and function [21]. Cells have developed an antioxidative system to manage ROS concentration under non-oxidative conditions, avoiding oxidation of other molecules and their dysfunction in the cell metabolism and architecture. Biochemically, antioxidants can be classified into two groups as enzymatic and non-enzymatic. Some examples of the former are catalases (CAT; EC 1.11.1.6), which are involved in $\mathrm{H}_{2} \mathrm{O}_{2}$ conversion into $\mathrm{O}_{2}$ and $\mathrm{H}_{2} \mathrm{O}$, and superoxide dismutases (SODs; EC 1.15.1.1), metalloenzymes that catalyse the $\mathrm{O}_{2}{ }^{--}$dismutation to $\mathrm{H}_{2} \mathrm{O}_{2}$ and $\mathrm{O}_{2}$ [22]. The ascobate-glutathione cycle is specific of higher plants and decomposes $\mathrm{H}_{2} \mathrm{O}_{2}$ into $\mathrm{H}_{2} \mathrm{O}$ by the former enzyme of the cycle ascorbate peroxidase, in a chain reaction which takes the required electrons from NADPH through the glutathione reductase, the last enzyme of the pathway [22,23]. This cycle integrates four antioxidative enzymes as well as two important non-enzymatic antioxidants: ascorbate (vitamin C) and glutathione. On the other hand, pepper fruits contain high levels of antioxidants such as ascorbate (vitamin C), B-carotene (provitamin A), and flavonoids as well as minerals [22,24]. Accordingly, a moderate increase in the concentration and/or in the enzymatic activities of antioxidants can be related to an improvement in growth and physiological development of plants.

The aim of this research is to study the feasibility of AL compost as an organic fertiliser for pepper growth under greenhouse conditions. Our hypothesis is that the organic matter from AL compost can positively affect pepper oxidative metabolism by increasing its antioxidative enzymatic activities and contents such as catalase, SODs or ascorbate and glutathione concentrations, and, hence, the yield and physiological development of plants would improve. To achieve this objective, different AL compost doses have been compared to the standard nutrient solution to test the optimal organic fertiliser rate in which pepper growth and yield are optimal using minimal inorganic fertilisers, and monitoring the cell status through the analysis of the oxidative metabolism. 


\section{Materials and Methods}

\subsection{Agrochemical Characterization of the AL Compost}

The AL compost was made by mixing two-phase olive mill waste (AL) with sheep manure $(1: 1, v / v)$ in an open trapezoidal pile of $10 t$, which was aerobically managed with mechanical turnings applied by a backhoe loader [11]. Moisture was kept above $40 \%$ using an aspersion system and the composting process lasted 22 weeks. The main agrochemical characteristics of the AL compost are presented in Table 1 . The $\mathrm{pH}$ was slightly alkaline $(7.67 \pm 0.23)$ and the salinity was low (EC of $1.11 \pm 0.08 \mathrm{dS} \mathrm{m}^{-1}$ ). Its organic matter content was $54.5 \pm 1.8 \%$, with an important lignocellulosic fraction and the humic content was notable, showing $78.30 \pm 3.39 \%$ humic acid $\left(\mathrm{P}_{\mathrm{HA}}\right)$. Total nitrogen content represented $1.50 \pm 0.30 \%$, essentially organic due to its low mineral nitrogen content (ammonium, nitrate and nitrite). Other agrochemical characteristics such as $T_{O C} / T_{N}$, macro- $(\mathrm{P}, \mathrm{K}, \mathrm{Ca}, \mathrm{Mg}, \mathrm{Na}$, and $\mathrm{S})$ and micronutrient $(\mathrm{Fe}, \mathrm{Cu}, \mathrm{Mn}$, and $\mathrm{Zn})$ and heavy metal $(\mathrm{Pb}, \mathrm{Cr}, \mathrm{Ni}$, $\mathrm{Cd}$, and $\mathrm{Hg}$ ) contents agreed with those reviewed previously [25]. Finally, the AL compost presented non-phytotoxic characteristics according to Zucconi test (GI (germination index) of $93 \pm 1 \%$ ).

Table 1. Main agrochemical characteristics of the AL compost.

\begin{tabular}{|c|c|c|c|}
\hline Parameters $^{1}$ & Mean & Standard Deviation & Coefficient of Variation (\%) \\
\hline Moisture & 38.5 & 2.2 & 6 \\
\hline $\mathrm{pH}^{2}$ & 7.67 & 0.23 & 3 \\
\hline $\mathrm{EC}^{2}\left(\mathrm{dS} \mathrm{m}^{-1}\right)$ & 1.11 & 0.08 & 7 \\
\hline $\mathrm{OM}(\%)$ & 54.5 & 1.8 & 3 \\
\hline Lignin $(\%)$ & 31.9 & 4.5 & 14 \\
\hline Cellulose (\%) & 15.8 & 2.2 & 14 \\
\hline Hemicellulose (\%) & 10.7 & 2.1 & 20 \\
\hline $\mathrm{T}_{\mathrm{OC}}(\%)$ & 25.27 & 0.03 & 0 \\
\hline $\mathrm{T}_{\mathrm{N}}(\%)$ & 1.50 & 0.30 & 20 \\
\hline $\mathrm{T}_{\mathrm{OC}} / \mathrm{T}_{\mathrm{N}}$ & 17.16 & 3.41 & 20 \\
\hline Fat content $(\%)$ & 0.35 & 0.07 & 20 \\
\hline WSC (\%) & 1.70 & 0.14 & 9 \\
\hline WSCH $(\%)$ & 0.30 & 0.14 & 47 \\
\hline WSPH $(\%)$ & 0.15 & 0.07 & 47 \\
\hline $\mathrm{HR}$ & 28.85 & 2.33 & 8 \\
\hline HD & 79.65 & 1.06 & 1 \\
\hline $\mathrm{P}_{\mathrm{HA}}(\%)$ & 78.30 & 3.39 & 4 \\
\hline $\mathrm{P}(\%)$ & 0.32 & 0.04 & 13 \\
\hline $\mathrm{K}(\%)$ & 1.14 & 0.17 & 15 \\
\hline $\mathrm{Ca}(\%)$ & 2.99 & 0.16 & 5 \\
\hline $\operatorname{Mg}(\%)$ & 0.63 & 0.12 & 19 \\
\hline $\mathrm{Na}(\%)$ & 0.10 & 0.03 & 28 \\
\hline $\mathrm{S}(\%)$ & 0.17 & 0.03 & 17 \\
\hline $\mathrm{Fe}(\%)$ & 0.86 & 0.01 & 2 \\
\hline $\mathrm{Cu}\left(\mathrm{mg} \mathrm{kg}^{-1}\right)$ & 30 & 2 & 7 \\
\hline $\operatorname{Mn}\left(\mathrm{mg} \mathrm{kg}^{-1}\right)$ & 221 & 30 & 13 \\
\hline $\mathrm{Zn}\left(\mathrm{mg} \mathrm{kg}^{-1}\right)$ & 55 & 4 & 6 \\
\hline $\mathrm{Pb}\left(\mathrm{mg} \mathrm{kg}^{-1}\right)$ & 16 & 1 & 9 \\
\hline $\mathrm{Cr}\left(\mathrm{mg} \mathrm{kg}^{-1}\right)$ & 35 & 6 & 18 \\
\hline $\mathrm{Ni}\left(\mathrm{mg} \mathrm{kg}^{-1}\right)$ & 17 & 2 & 13 \\
\hline $\mathrm{Cd}\left(\mathrm{mg} \mathrm{kg}^{-1}\right)$ & $<0.025$ & - & - \\
\hline $\mathrm{Hg}\left(\mathrm{mg} \mathrm{kg}^{-1}\right)$ & $<0.025$ & - & - \\
\hline GI & 93 & 1 & 2 \\
\hline
\end{tabular}

1 Data based on dry weight. ${ }^{2}$ Water extract 1:10 $(w / v)$. EC: electrical conductivity; OM: total organic matter; $\mathrm{T}_{\mathrm{OC}}$ : total organic carbon; $\mathrm{T}_{\mathrm{N}}$ : total nitrogen; WSC: water-soluble organic carbon; WSCH: water-soluble carbohydrates; WSPH: water-soluble phenols; HR: humification ratio; HD: humification degree; $\mathrm{P}_{\mathrm{HA}}$ : percentage of humic acids; GI: Germination index by Zucconi Test; -: not detected. 


\subsection{Pepper Growth Conditions}

California type pepper (Capsicum annuum L.) seeds were provided by Syngenta Seeds S.A. (El Ejido, Almería, Spain) and were surface-sterilized by adding $\mathrm{NaClO} 5 \%(v / v)$ for $5 \mathrm{~min}$, germinated in Petri dishes and further grown in vermiculite (No. 3) during 30 days at $25^{\circ} \mathrm{C}$. After that, selected seedlings were planted in pots $(2.5 \mathrm{~L})$ filled with vermiculite/perlite $(1: 1, v / v)$ as a growing substrate (one seedling per pot). AL compost was added according to each treatment and pots were watered three times per week $(200 \mathrm{~mL})$ : twice with distilled water and once using a modified Hewitt nutrient solution (NS) [26] consisting of $\mathrm{KH}_{2} \mathrm{PO}_{4} 1.15 \mathrm{mM}, \mathrm{Ca}\left(\mathrm{NO}_{3}\right)_{2} 3.10 \mathrm{mM}, \mathrm{Mg}\left(\mathrm{NO}_{3}\right)_{2} 2.56 \mathrm{mM}, \mathrm{KNO}_{3} 3.6 \mathrm{mM}$, $\mathrm{H}_{3} \mathrm{BO}_{3} 46.2 \mu \mathrm{M}, \mathrm{MnSO}_{4} 9.10 \mu \mathrm{M}, \mathrm{CuSO}_{4} 0.79 \mu \mathrm{M}, \mathrm{ZnSO}_{4} 3.06 \mu \mathrm{M},\left(\mathrm{NH}_{4}\right)_{6} \mathrm{Mo}_{7} \mathrm{O}_{24} 0.05 \mu \mathrm{M}$ and EDDHA-Fe $0.18 \mathrm{mM}$.

During the whole experiment, two harvests were done: the former at the beginning of flowering, when nutrient demand was more intense, and the latter, during fruit development. Pepper plants were grown in a controlled plant-growing greenhouse with day/night temperatures of $25-20{ }^{\circ} \mathrm{C}$ and photosynthesis photon flux density of $180 \mu \mathrm{mol}$ photons $\mathrm{m}^{2} \mathrm{~s}^{-1}$. The facilities of the Greenhouse and Growth Chambers Service of Estación Experimental del Zaidín (EEZ-CSIC, Granada, Spain) were used for growing plants.

\subsection{Experimental Design and Statistical Analysis}

To test AL compost effectiveness on pepper growth and yield, two experiments were conducted:

(1) In the First experiment, AL compost was added as an organic fertiliser (Exp. No. 1). According to this, three treatments were assayed: NS (no AL compost added and watered with the modified Hewitt nutrient solution mentioned before), C (50\% AL compost, $v / v$, and only watered with distilled water) and C + NS (50\% AL compost, $v / v$, and watered with the modified Hewitt nutrient solution mentioned before). In C and NS treatments, similar total nitrogen concentration was added with differences in its chemical forms: in the former, compost nitrogen was predominantly in the organic form (Table 1), whereas, in the latter treatment (NS), nitrogen was added under nitrate form (easily assimilable). The total amount of $\mathrm{NO}_{3}{ }^{-}$added in NS and $\mathrm{C}+\mathrm{NS}$ treatments was $2.77 \mathrm{~g}$. Finally, a combination of both treatments $(\mathrm{C}+\mathrm{NS})$ was also done to test synergistic effect between AL compost and nitrate. According to physiological evolution, flowering of pepper plants started at 78 days after seeds sowing (first harvest) and the pepper fruits production was monitored at 107 days (second harvest).

(2) Based on the obtained results in Exp. No. 1, a Second experiment (Exp. No. 2) was developed without any nitrogen limitations. Then, four treatments were performed: Control (no AL compost added), $\mathrm{C} 1$ ( $8 \%$ of AL compost, $v / v), \mathrm{C} 2$ (17\% of AL compost, $v / v)$ and C3 (33\% of AL compost, $v / v$ ). Control treatment was watered using the modified Hewitt mineral solution described before, and $\mathrm{C} 1, \mathrm{C} 2$ and $\mathrm{C} 3$ were watered only with $\mathrm{NO}_{3}{ }^{-} 14.92 \mathrm{mM}$. For each treatment, the total amount of $\mathrm{NO}_{3}{ }^{-}$added was $3.33 \mathrm{~g}$, respectively. Pepper plant flowering started at 98 days after seeds sowing (first harvest) and pepper fruits were harvested at 127 days (second harvest).

In each experiment, eight pots per treatment were set using the randomized blocks procedure $\left(2^{\mathrm{n}}\right)$. For each treatment, a descriptive statistical analysis (mean, absolute and relative errors) of the data $(n=8)$ was carried out. Assuming the normal distribution and homoscedasticity of the data, inferential statistical analysis such as the analysis of variance (ANOVA) within treatments were calculated to test AL compost doses effects on peppers' growth and yield. Tukey-Kramer test $(p<0.05)$ was used as a post-hoc analysis. Statistical analysis was performed using GNU-PSPP open-source software v0.9.0 (available in https://www.gnu.org/software/pspp/).

\subsection{Chemical and Biochemical Analysis}

Plants were divided into shoots, roots and fruits and fresh representative samples were frozen by adding liquid nitrogen and stored at $-80{ }^{\circ} \mathrm{C}$ until enzymatic analysis were done. Shoot (SDW) 
and root dry weights (RDW) were measured per plant using an oven at $70{ }^{\circ} \mathrm{C}$ until constant weight. After that, plant samples were ground to powder using an IKA A11 mill to less than $0.5 \mathrm{~mm}$ prior to chemical analysis. Total organic carbon $\left(\mathrm{T}_{\mathrm{OC}}\right)$ and total nitrogen $\left(\mathrm{T}_{\mathrm{N}}\right)$ were determined according to Dumas method using a LECO TruSpec CN Elemental Analyzer. Other macro- and micronutrient (P, K, $\mathrm{Ca}, \mathrm{Mg}, \mathrm{Na}, \mathrm{S}, \mathrm{Fe}, \mathrm{Cu}, \mathrm{Mn}$, and $\mathrm{Zn})$ and heavy metal $(\mathrm{Pb}, \mathrm{Cr}, \mathrm{Ni}, \mathrm{Cd}$ and $\mathrm{Hg}$ ) contents were determined by Inductively Coupled Plasma Optical Emission Spectrometry (ICP-OES) after microwave digestion with a HCl-HF (1:1) mixture. These analyses were carried out at the Instrumental Technical Services of the Estación Experimental del Zaidín (EEZ-CSIC). For the antioxidant assays, ultra-frozen and powdered plant tissues were suspended in a buffer solution $(1: 4, w / v)$ containing Tris- $\mathrm{HCl}(\mathrm{pH} 8.0)$ $0.1 \mathrm{M}$, EDTA $0.2 \mathrm{mM}$, Triton X-100 0.1\% $(v / v)$, glycerol 10\% $(v / v)$ and dithiothreitol (DTT) $5 \mathrm{mM}$. Homogenates were centrifuged at $27,000 \mathrm{~g}$ for $25 \mathrm{~min}$ at $4{ }^{\circ} \mathrm{C}$ and supernatants were immediately used for the assays. Total protein content was determined by the dye binding microassay using the Bradford reagent (Bio-Rad, Hercules, CA, USA) [27] and BSA as standard. Catalase (CAT; EC 1.11.1.6) activity was determined by measuring spectrophotometrically $\left(\lambda=240 \mathrm{~nm}, \varepsilon=39.58 \times 10^{-3} \mathrm{M}^{-1} \mathrm{~cm}^{-1}\right)$ the enzymatic decrease of $\mathrm{H}_{2} \mathrm{O}_{2}$ throughout time in the presence of phosphate buffer $50 \mathrm{mM}, \mathrm{pH} 7.0$ [28]. Results were expressed as $\mathrm{mmol} \mathrm{H}_{2} \mathrm{O}_{2} \mathrm{~min}^{-1} \mathrm{mg}^{-1}$ total protein. Total superoxide dismutase activity (SOD; EC 1.15.1.1) was assayed by measuring the ferricytochrome $\mathrm{c}$ reduction produced by the superoxide radicals $\left(\mathrm{O}_{2}{ }^{--}\right)$generated by the xanthine/xanthine oxidase system [29]. The specific activity was expressed as $\mathrm{U} \mathrm{mg}^{-1}$ total protein, where one Unit was defined as the amount of SOD which produces a 50\% inhibition of the ferricytochrome c reduction. In addition, the SOD isozymes profile was investigated by non-denaturing gel electrophoresis (PAGE) of proteins and further specific NBT staining of gels [30]. Isozymes were identified in gels by using inhibitors. Thus, CuZn-SODs are inhibited by cyanide and $\mathrm{H}_{2} \mathrm{O}_{2}$, Fe-SODs are inhibited by $\mathrm{H}_{2} \mathrm{O}_{2}$, whereas Mn-SODs are resistant to both inhibitors. Lipid peroxidation was determined spectrophotometrically $(\lambda=535 \mathrm{~nm})$ by measuring the concentration of thiobarbituric acid-reacting substances (TBARS), using malondialdehyde (MDA) as a standard [31]. Results were expressed as nmol MDA g ${ }^{-1}$ fresh weight. Ascorbate was determined by HPLC after incubation of $0.5 \mathrm{~g}$ of fresh sample with $\mathrm{m}$-phosphoric acid $(5 \%, w / w)$ during $30 \mathrm{~min}$ at $4{ }^{\circ} \mathrm{C}$. The extract was centrifuged at $12,000 \mathrm{~g}$ for $10 \mathrm{~min}$ and filtered with $0.45 \mu \mathrm{m}$ nylon-based filters [32]. Finally, total glutathione and reduced and oxidized glutathione (GSH and GSSG) were analysed by LC-ES/MS [33].

\section{Results}

\subsection{AL Compost as an Organic Fertiliser (Exp. No. 1)}

The effect of AL compost in pepper growth and yield is shown in Table 2. C treatment showed an important decline, especially in the SDW and fruit yield compared to NS or C + NS treatments. Although all treatments received similar total nitrogen concentration, the chemical form applied was different. Inorganic nitrogen (nitrate) was used in NS treatment meanwhile the nitrogen in C treatment was mainly organic. It seems that 107 days was not enough time for the organic nitrogen mineralization, being not easily available by pepper roots. For that reason, pepper plants of $C$ treatment did not render any fruit at the end of the experiments. At the other harvest time, in C treatment, the AL compost favoured root development in pepper plants, especially during flowering, being close to three- and two-fold the values recorded in NS and C + NS plants, respectively.

The combined treatment $(\mathrm{C}+\mathrm{NS})$ presented the best results in pepper growth and yield, showing a statistical increase in SDW, RDW (except at flowering), number of fruits and yield per plant, compared to NS or C treatments.

Macro- and micronutrient concentrations in pepper leaves from $C$ treatment were lower than those obtained from both NS and C + NS treatments (Table 3). The synergy exposed above for C + NS treatment was only observed for $\mathrm{T}_{\mathrm{N}}$ and $\mathrm{K}$ concentrations, with $5.54 \pm 0.98$ and $3.18 \pm 0.34 \%$ for $\mathrm{T}_{\mathrm{N}}$ and $38.2 \pm 2.6$ and $23.7 \pm 1.9 \mathrm{~g} \mathrm{~kg}^{-1}$ for $\mathrm{K}$ at the first and second harvests, respectively. These concentrations 
were higher at flowering than at fruit setting stages, especially due to the increase of the pepper shoot tissue analysed (Table 2).

The catalase activity from leaves revealed that pepper plants grown in $C$ treatment experienced a noteworthy increase in both growth phases (Table 4). According to this, catalase activity in C treatment was about three- and two-fold compared to C + NS or NS treatments, respectively. The SOD isozyme profile (Figure 1) showed four bands according to the behaviour with inhibitors: one Mn-SOD, one Fe-SOD, and two CuZn-SODs, designated as CuZn-SOD I and II depending on their increasing electrophoretic mobility. This pattern agrees with the one previously reported for crude extracts from pepper leaves [21]. Mn-SOD, CuZn-SOD I and, especially, CuZn-SOD II were more intense in C treatment than those obtained in NS or C + NS, mainly at the first harvest, what means that those isoezymes were, perhaps, over-expressed. In addition, the ascorbate content in pepper leaves was slightly higher in C treatment compared to NS or C + NS, although they did not show statistical differences $(p<0.05)$ among treatments (Table 4$)$ in both dates. By contrast, pepper leaves from $C$ treatment showed a lower glutathione content. Interestingly, values of ascorbate and glutathione were down which could indicate that the potentiality of plants to synthesize them decreased or that these antioxidants are moved towards the reproductive organs to ensure the survival of the next generation. However, the most plausible hypothesis is that they are possibly consumed for the development of the plant since the oxidised form (GSSG) considerably increased at the end of the experiment with very low GSH/GSSG ratios (Table 4). As a concluding remark, it seems that nitrogen availability was the principal nutrient limitation affecting pepper growth under conditions in Exp. No. 1. AL compost applied was not enough to supply the nitrogen requirements of plants, perhaps because it was provided under organic nature, non-easily assimilable.

Table 2. Growth parameters in pepper plants and fruits after culture in the absence and the presence of AL compost. Exp. No. 1: NS, plants grown with full nutrient solution; C, plants only grown with compost; $\mathrm{C}+\mathrm{NS}$, plants grown with compost and complemented with full nutrient solution. Exp. No. 2: Control, plants grown with full nutrient solution; $\mathrm{C} 1, \mathrm{C} 2$, and $\mathrm{C} 3$, plants grown with $8 \%$, $17 \%$, and $33 \%(v / v)$ compost, respectively, and supplemented with $\mathrm{NO}_{3}{ }^{-} 14.92 \mathrm{mM}$.

\begin{tabular}{|c|c|c|c|c|c|}
\hline Exp. No. 1 & Treatment & SDW (g) & RDW (g) & $\begin{array}{c}\text { Number of Fruits } \\
\text { per Plant }\end{array}$ & $\begin{array}{l}\text { Yield of Pepper } \\
\text { Fruits per Plant (g) }\end{array}$ \\
\hline \multicolumn{6}{|l|}{ Harvest } \\
\hline \multirow{3}{*}{78 days } & NS & $3.9 \mathrm{~b}$ & $1.9 \mathrm{~b}$ & 0.0 & 0.0 \\
\hline & $C$ & $1.3 \mathrm{a}$ & $3.7 \mathrm{c}$ & 0.0 & 0.0 \\
\hline & $\mathrm{C}+\mathrm{NS}$ & $5.5 \mathrm{c}$ & $1.2 \mathrm{a}$ & 0.0 & 0.0 \\
\hline \multirow{3}{*}{107 days } & NS & $15.9 \mathrm{~b}$ & $4.9 \mathrm{a}$ & $3.1 \mathrm{a}$ & $43.1 \mathrm{a}$ \\
\hline & $\mathrm{C}$ & $2.0 \mathrm{a}$ & $5.1 \mathrm{a}$ & 0.0 & 0.0 \\
\hline & $\mathrm{C}+\mathrm{NS}$ & $20.3 \mathrm{c}$ & $7.2 \mathrm{~b}$ & $3.3 \mathrm{~b}$ & $45.6 \mathrm{~b}$ \\
\hline \multicolumn{6}{|l|}{ Exp. No. 2} \\
\hline \multicolumn{6}{|l|}{ Harvest } \\
\hline \multirow{4}{*}{98 days } & Control & $1.6 \mathrm{a}$ & $1.5 \mathrm{a}$ & 0.0 & 0.0 \\
\hline & $\mathrm{C} 1$ & $3.5 \mathrm{~b}$ & $3.2 b$ & 0.0 & 0.0 \\
\hline & $\mathrm{C} 2$ & $5.1 \mathrm{c}$ & $5.7 c$ & 0.0 & 0.0 \\
\hline & $\mathrm{C} 3$ & $6.8 \mathrm{~d}$ & $5.9 \mathrm{c}$ & 0.0 & 0.0 \\
\hline \multirow{4}{*}{127 days } & Control & $7.7 \mathrm{a}$ & $7.9 \mathrm{a}$ & $1.3 \mathrm{a}$ & $19.0 \mathrm{a}$ \\
\hline & $\mathrm{C} 1$ & $8.0 \mathrm{a}$ & $7.5 \mathrm{a}$ & $2.0 \mathrm{c}$ & $37.4 \mathrm{~b}$ \\
\hline & $\mathrm{C} 2$ & $10.6 \mathrm{~b}$ & $12.4 \mathrm{c}$ & $1.6 \mathrm{~b}$ & $47.6 \mathrm{~b}$ \\
\hline & C3 & $9.2 \mathrm{~b}$ & $10.6 \mathrm{~b}$ & $2.0 \mathrm{c}$ & $72.5 \mathrm{c}$ \\
\hline
\end{tabular}

Note: Data represent the mean of eight independent replicates. For each column and sampling date, values followed by the same lower-case letter among treatments are not statistically different according to one-way ANOVA with Tukey-Kramer post-hoc test at $p<0.05$. SDW, shoot dry weight. RDW, root dry weight. 
Table 3. Macro and micronutrient concentrations in pepper shoots and fruits from Exp. No. 1 according to each harvest and treatments. NS, plants grown with full nutrient solution; $\mathrm{C}$, plants only grown with compost; $\mathrm{C}+\mathrm{NS}$, plants grown with compost and complemented with full nutrient solution.

\begin{tabular}{|c|c|c|c|c|c|c|}
\hline \multirow[b]{2}{*}{ Harvest } & \multicolumn{6}{|c|}{ Exp. No. 1} \\
\hline & \multicolumn{3}{|c|}{78 days } & \multicolumn{3}{|c|}{107 days } \\
\hline Plant Organ & \multicolumn{6}{|c|}{ Shoots } \\
\hline Nutrients $^{1}$ & NS & $\mathrm{C}$ & $\mathrm{C}+\mathrm{NS}$ & NS & $\mathrm{C}$ & $\mathrm{C}+\mathrm{NS}$ \\
\hline $\mathrm{T}_{\mathrm{OC}}(\%)$ & $38.03 \mathrm{a}$ & $40.43 \mathrm{a}$ & $38.47 \mathrm{a}$ & $41.00 \mathrm{a}$ & $40.47 \mathrm{a}$ & $40.67 \mathrm{a}$ \\
\hline $\mathrm{T}_{\mathrm{N}}(\%)$ & $5.17 \mathrm{~b}$ & $2.32 \mathrm{a}$ & $5.54 \mathrm{c}$ & $2.81 \mathrm{~b}$ & $1.29 \mathrm{a}$ & $3.18 c$ \\
\hline$P\left(\mathrm{~g} \mathrm{~kg}^{-1}\right)$ & $3.0 \mathrm{c}$ & $1.7 \mathrm{a}$ & $2.2 \mathrm{~b}$ & $2.2 \mathrm{~b}$ & $1.6 \mathrm{a}$ & $2.0 \mathrm{~b}$ \\
\hline $\mathrm{K}\left(\mathrm{g} \mathrm{kg}^{-1}\right)$ & $35.9 \mathrm{~b}$ & $27.7 \mathrm{a}$ & $38.2 \mathrm{c}$ & $22.8 \mathrm{a}$ & $24.1 \mathrm{a}$ & $23.7 \mathrm{a}$ \\
\hline $\mathrm{Ca}\left(\mathrm{g} \mathrm{kg}^{-1}\right)$ & $17.2 \mathrm{~b}$ & $6.5 \mathrm{a}$ & $16.1 \mathrm{~b}$ & $11.2 \mathrm{~b}$ & $6.5 \mathrm{a}$ & $12.5 \mathrm{~b}$ \\
\hline $\operatorname{Mg}\left(\mathrm{g} \mathrm{kg}^{-1}\right)$ & $10.7 \mathrm{~b}$ & $5.9 \mathrm{a}$ & $11.1 \mathrm{~b}$ & $5.2 \mathrm{a}$ & $5.1 \mathrm{a}$ & $6.6 \mathrm{~b}$ \\
\hline $\mathrm{Na}\left(\mathrm{g} \mathrm{kg}^{-1}\right)$ & $0.1 \mathrm{a}$ & $0.1 \mathrm{a}$ & $0.1 \mathrm{a}$ & $0.1 \mathrm{a}$ & $0.1 \mathrm{a}$ & $0.1 \mathrm{a}$ \\
\hline $\mathrm{S}\left(\mathrm{g} \mathrm{kg}^{-1}\right)$ & $4.7 \mathrm{~b}$ & $2.3 \mathrm{a}$ & $5.1 \mathrm{~b}$ & $3.5 \mathrm{~b}$ & $1.8 \mathrm{a}$ & $3.8 \mathrm{~b}$ \\
\hline $\mathrm{Fe}\left(\mathrm{mg} \mathrm{kg}^{-1}\right)$ & $238 \mathrm{c}$ & $92 \mathrm{a}$ & $213 b$ & $100 \mathrm{~b}$ & $40 \mathrm{a}$ & $98 \mathrm{~b}$ \\
\hline $\mathrm{Cu}\left(\mathrm{mg} \mathrm{kg}^{-1}\right)$ & $24 \mathrm{~b}$ & $10 \mathrm{a}$ & $31 \mathrm{~b}$ & $11 \mathrm{a}$ & $5 a$ & $16 \mathrm{a}$ \\
\hline $\mathrm{Mn}\left(\mathrm{mg} \mathrm{kg}^{-1}\right)$ & 192 c & $128 \mathrm{a}$ & $159 \mathrm{~b}$ & $86 a$ & $128 \mathrm{~b}$ & $95 \mathrm{a}$ \\
\hline $\mathrm{Zn}\left(\mathrm{mg} \mathrm{kg}^{-1}\right)$ & $13 \mathrm{a}$ & $14 \mathrm{a}$ & $16 \mathrm{a}$ & $13 \mathrm{a}$ & $15 \mathrm{a}$ & $11 \mathrm{a}$ \\
\hline
\end{tabular}

${ }^{1}$ Data based on dry weight. Note: Data represent the mean of eight independent replicates. For each nutrient, harvest and plants organ, values followed by the same lower-case letter among treatments (NS, C and C + NS, respectively) are not statistically different according to one-way ANOVA with Tukey-Kramer post-hoc test at $p<0.05$. $\mathrm{T}_{\mathrm{OC}}$ : total organic carbon. $\mathrm{T}_{\mathrm{N}}$ : total nitrogen.

Table 4. Catalase activity, ascorbate, glutathione, reduced (GSH) and oxidized glutathione (GSSG) contents determined in pepper leaves of Exp. No. 1 according to treatments assayed. Data were collected from the onset of flowering (78 days) until fruit harvesting (107 days). NS, plants grown with full nutrient solution; $C$, plants only grown with compost; $C+N S$, plants grown with compost and complemented with full nutrient solution.

\begin{tabular}{|c|c|c|c|c|c|c|c|}
\hline $\begin{array}{l}\text { Exp. No. } 1 \\
\text { Harvest }\end{array}$ & Treatments & $\begin{array}{c}\text { Catalase Activity ( } \mu \mathrm{mol} \\
\mathrm{H}_{2} \mathrm{O}_{2} \text { min }^{-1} \mathrm{mg}^{-1} \text { Protein) }\end{array}$ & $\begin{array}{c}\text { Ascorbate } \\
\left(\mu \mathrm{mol} \mathrm{g}{ }^{-1} \mathrm{FW}\right)\end{array}$ & $\begin{array}{c}\text { Glutathione } \\
\left(\text { nmol g }{ }^{-1} \text { FW) }\right.\end{array}$ & $\begin{array}{c}\text { GSH } \\
\left(\mathrm{nmol} \mathrm{g}^{-1} \mathrm{FW}\right)\end{array}$ & $\begin{array}{c}\text { GSSG } \\
\left(\mathrm{nmol} \mathrm{g}^{-1} \mathrm{FW}\right)\end{array}$ & GSH/GSSG \\
\hline \multirow{3}{*}{78 days } & NS & $11.40 \mathrm{a}$ & $1.240 \mathrm{a}$ & $142 \mathrm{~b}$ & $129 \mathrm{~b}$ & $13 \mathrm{a}$ & 10 \\
\hline & C & $35.46 \mathrm{~b}$ & $1.492 \mathrm{a}$ & $110 \mathrm{a}$ & $97 \mathrm{a}$ & $12 \mathrm{a}$ & 8 \\
\hline & $\mathrm{C}+\mathrm{NS}$ & $11.28 \mathrm{a}$ & $1.112 \mathrm{a}$ & $164 \mathrm{c}$ & $151 \mathrm{c}$ & $13 \mathrm{a}$ & 12 \\
\hline \multirow{3}{*}{107 days } & NS & $19.34 \mathrm{a}$ & $0.905 \mathrm{a}$ & $91 \mathrm{~b}$ & $11 \mathrm{a}$ & $80 \mathrm{~b}$ & 0.1 \\
\hline & C & $25.13 b$ & $1.278 \mathrm{a}$ & $71 \mathrm{a}$ & $22 \mathrm{a}$ & $49 \mathrm{a}$ & 0.4 \\
\hline & $\mathrm{C}+\mathrm{NS}$ & $13.18 \mathrm{a}$ & $1.021 \mathrm{a}$ & $52 \mathrm{a}$ & $17 \mathrm{a}$ & 35 a & 0.5 \\
\hline
\end{tabular}

Note: Data represent the mean of eight independent replicates. For each column, values followed by the same lower-case letter among treatments are not statistically different according to one-way ANOVA with Tukey-Kramer post-hoc test at $p<0.05$.

\subsection{AL Compost Supplemented with Nitrate (Exp. No. 2)}

Based on the previous results obtained in Exp. No. 1, a new experiment was carried out avoiding $\mathrm{N}$ deficiency through the strategy of complementing AL compost with nitrate $14.92 \mathrm{mM}$. According to this, an improvement in the pepper plant growth and development was recorded with increasing physiological parameters as the AL compost doses were applied (Table 2). This effect was observed at both harvests, especially at flowering (98 days), when the nutrient demand was more intense. Thus, SDW and RDW were augmented significantly with AL compost doses, being close to four-fold in C3 treatment compared to those obtained in Control treatment. In addition, AL compost doses produced an improvement in fruit production, especially in pepper yield, C3 being the treatment with the highest pepper yield, around four-fold, compared to those obtained in Control treatment.

In general, the macro- and micronutrient concentrations in pepper leaves were slightly higher in Control treatment compared to C1, C2 and C3 (Table 5). K represented an exception since it was supplied as $\mathrm{KNO}_{3} 14.92 \mathrm{mM}$ used for plant watering. This behaviour was notable at both harvests, 
especially for $\mathrm{T}_{\mathrm{N}}, \mathrm{P}, \mathrm{Fe}$ and Mn during flowering. By contrast, no tendency was observed in the statistical differences in pepper fruits among treatments.

The effect of the AL compost doses on the catalase activity from pepper leaves was also studied (Table 6). A statistical increase in $C$ treatments was found at both harvests, especially notable during flowering and with the highest dose of compost (C3). This last treatment showed values at the first harvest which were near two-fold the Control treatment, although similar but still statistically different at the second harvest.

On the other hand, the lipid peroxidation in pepper leaves showed a similar tendency as occurred with catalase activity in both harvests, but without any statistical significance (Table 6). That means that the pepper leaves experienced an increase in the oxidative metabolism but they did not undergo any oxidative stress symptoms within AL compost doses applied.

Regarding the SOD isozyme profile, it was found that the Mn-SOD and the Fe-SOD were more intense at the flowering harvest (98 days), in treatments $\mathrm{C} 1, \mathrm{C} 2$ and $\mathrm{C} 3$ compared to those obtained from Control treatment (Figure 1B). The CuZn-SOD isozymes displayed an opposite pattern in compost-grown plants with respect to Control ones. Thus, whereas CuZn-SOD I and II were more intense at the fruit stage than at flowering, in plants treated with compost, $\mathrm{C} 1, \mathrm{C} 2$ or $\mathrm{C} 3$, these isozymes depicted higher activity at the first harvest (98 days). The overall results of the isoenzymatic activity correlated with the total SOD activity (Figure 2), in which compost treatments showed a statistical increase compared to Control treatment, being C3, where SOD activity showed the highest values, seven-fold the Control. Glutathione content and its reduced (GSH) and oxidized (GSSG) forms were also analysed in pepper fruits at the end of the experiment (Figure 3). According to those data, it can be concluded that the concentration profile of those antioxidants was not affected by any of the treatments assayed, being the reduced form (GSH) predominant in recollected pepper fruits with the ratio GSH/GSSG about 8-10 in all cases. Most interestingly, ascorbate content was affected by all AL composts doses (Figure 4). A statistical increase was registered in ascorbate contents in pepper fruits in $\mathrm{C} 1, \mathrm{C} 2$ and $\mathrm{C} 3$ compared to Control treatment, but no statistical differences among AL composts doses applied were registered.

Table 5. Macro- and micronutrient concentrations in pepper shoots and fruits from Exp. No. 2 according to each harvest and treatments. Control, plants grown with full nutrient solution; C1, C2, and $\mathrm{C} 3$, plants grown with $8 \%, 17 \%$, and $33 \%(v / v)$ compost, respectively, and supplemented with $\mathrm{NO}_{3}-14.92 \mathrm{mM}$.

\begin{tabular}{|c|c|c|c|c|c|c|c|c|c|c|c|c|}
\hline \multirow{4}{*}{$\begin{array}{c}\text { Harvest } \\
\text { Plant Organ } \\
\text { Nutrients }{ }^{1}\end{array}$} & \multicolumn{12}{|c|}{ Exp. No. 2} \\
\hline & \multirow{2}{*}{\multicolumn{4}{|c|}{$\begin{array}{l}98 \text { days } \\
\text { Shoots }\end{array}$}} & \multicolumn{8}{|c|}{127 days } \\
\hline & & & & & \multicolumn{4}{|c|}{ Shoots } & \multicolumn{4}{|c|}{ Fruits } \\
\hline & Control & $\mathrm{C} 1$ & $\mathrm{C} 2$ & $\mathrm{C} 3$ & Control & $\mathrm{C} 1$ & $\mathrm{C} 2$ & $\mathrm{C} 3$ & Control & $\mathrm{C} 1$ & $\mathrm{C} 2$ & $\mathrm{C} 3$ \\
\hline $\mathrm{T}_{\mathrm{OC}}(\%)$ & $36.95 \mathrm{a}$ & $37.45 \mathrm{~b}$ & $37.50 \mathrm{~b}$ & $38.20 \mathrm{~b}$ & $38.90 \mathrm{a}$ & $37.90 \mathrm{a}$ & $39.00 \mathrm{~b}$ & $37.90 \mathrm{a}$ & $50.30 \mathrm{c}$ & $44.90 \mathrm{a}$ & $47.20 \mathrm{~b}$ & $45.80 \mathrm{a}$ \\
\hline $\mathrm{T}_{\mathrm{N}}(\%)$ & $4.79 c$ & $4.72 \mathrm{c}$ & $3.76 \mathrm{~b}$ & $2.78 \mathrm{a}$ & $2.53 \mathrm{~b}$ & $2.71 \mathrm{c}$ & $2.31 \mathrm{a}$ & $2.10 \mathrm{a}$ & $1.31 \mathrm{a}$ & $1.72 \mathrm{c}$ & $1.93 \mathrm{~d}$ & $1.46 \mathrm{~b}$ \\
\hline $\mathrm{P}\left(\mathrm{g} \mathrm{kg}^{-1}\right)$ & $4.9 \mathrm{c}$ & $2.4 \mathrm{a}$ & $3.0 \mathrm{~b}$ & $2.6 \mathrm{a}$ & $1.4 \mathrm{c}$ & $0.8 \mathrm{a}$ & $1.2 \mathrm{~b}$ & $1.2 \mathrm{~b}$ & $2.3 \mathrm{~b}$ & $1.4 \mathrm{a}$ & $2.2 \mathrm{~b}$ & $2.5 \mathrm{c}$ \\
\hline $\mathrm{K}\left(\mathrm{g} \mathrm{kg}^{-1}\right)$ & $39.9 \mathrm{~d}$ & $36.1 \mathrm{~b}$ & $37.7 \mathrm{c}$ & $31.7 \mathrm{a}$ & $29.0 \mathrm{a}$ & $28.6 \mathrm{a}$ & $30.2 \mathrm{a}$ & $29.6 \mathrm{a}$ & $19.4 \mathrm{~b}$ & $17.3 \mathrm{a}$ & $18.5 \mathrm{a}$ & $17.7 \mathrm{a}$ \\
\hline $\mathrm{Ca}\left(\mathrm{g} \mathrm{kg}^{-1}\right)$ & $12.7 \mathrm{~b}$ & $11.6 \mathrm{a}$ & $13.5 \mathrm{~b}$ & $11.1 \mathrm{a}$ & $9.9 \mathrm{a}$ & $14.6 \mathrm{~b}$ & $14.0 \mathrm{~b}$ & $16.3 \mathrm{c}$ & $0.6 \mathrm{a}$ & $1.0 \mathrm{~b}$ & $1.0 \mathrm{~b}$ & $0.9 \mathrm{~b}$ \\
\hline $\mathrm{Mg}\left(\mathrm{g} \mathrm{kg}^{-1}\right)$ & $12.4 \mathrm{c}$ & $9.9 \mathrm{~b}$ & $9.7 \mathrm{~b}$ & $5.5 \mathrm{a}$ & $8.0 \mathrm{~b}$ & $7.8 \mathrm{~b}$ & $6.8 \mathrm{~b}$ & $5.6 \mathrm{a}$ & $1.3 \mathrm{a}$ & $1.1 \mathrm{a}$ & $1.3 \mathrm{a}$ & $1.2 \mathrm{a}$ \\
\hline $\mathrm{Na}\left(\mathrm{g} \mathrm{kg}^{-1}\right)$ & $0.3 \mathrm{~b}$ & $0.1 \mathrm{a}$ & $0.1 \mathrm{a}$ & $0.0 \mathrm{a}$ & $0.0 \mathrm{a}$ & $0.0 \mathrm{a}$ & $0.0 \mathrm{a}$ & $0.0 \mathrm{a}$ & $0.0 \mathrm{a}$ & $0.0 \mathrm{a}$ & $0.0 \mathrm{a}$ & $0.0 \mathrm{a}$ \\
\hline $\mathrm{S}\left(\mathrm{g} \mathrm{kg}^{-1}\right)$ & $5.3 \mathrm{c}$ & $3.6 \mathrm{~b}$ & $3.4 \mathrm{~b}$ & $2.2 \mathrm{a}$ & $4.6 \mathrm{~b}$ & $2.5 \mathrm{a}$ & $2.2 \mathrm{a}$ & $2.0 \mathrm{a}$ & $1.8 \mathrm{c}$ & $1.5 \mathrm{~b}$ & $1.6 \mathrm{~b}$ & $1.3 \mathrm{a}$ \\
\hline $\mathrm{Fe}\left(\mathrm{mg} \mathrm{kg}^{-1}\right)$ & $386 \mathrm{~d}$ & $120 \mathrm{~b}$ & $143 \mathrm{c}$ & $81 \mathrm{a}$ & $157 \mathrm{~d}$ & $66 \mathrm{~b}$ & $82 \mathrm{c}$ & $56 a$ & $100 \mathrm{~b}$ & $79 a$ & $94 \mathrm{~b}$ & $73 \mathrm{a}$ \\
\hline $\mathrm{Cu}\left(\mathrm{mg} \mathrm{kg}^{-1}\right)$ & $20 \mathrm{c}$ & $9 \mathrm{~b}$ & $8 \mathrm{~b}$ & $6 a$ & $12 \mathrm{~b}$ & $5 a$ & $5 \mathrm{a}$ & $5 a$ & $12 \mathrm{~b}$ & $6 a$ & $6 a$ & $6 a$ \\
\hline $\operatorname{Mn}\left(\mathrm{mg} \mathrm{kg}^{-1}\right)$ & $124 \mathrm{~d}$ & $57 \mathrm{~b}$ & $68 c$ & $42 \mathrm{a}$ & $87 \mathrm{c}$ & $47 \mathrm{a}$ & $59 \mathrm{~b}$ & $59 \mathrm{~b}$ & $14 \mathrm{~b}$ & $11 \mathrm{a}$ & $14 \mathrm{~b}$ & $13 \mathrm{~b}$ \\
\hline $\mathrm{Zn}\left(\mathrm{mg} \mathrm{kg}^{-1}\right)$ & $44 \mathrm{c}$ & $28 \mathrm{a}$ & $32 \mathrm{~b}$ & $29 \mathrm{a}$ & $34 \mathrm{~b}$ & $18 \mathrm{a}$ & $17 \mathrm{a}$ & $31 \mathrm{~b}$ & $24 \mathrm{a}$ & $30 \mathrm{~b}$ & $44 \mathrm{c}$ & $41 \mathrm{c}$ \\
\hline
\end{tabular}

${ }^{1}$ Data based on dry weight. Note: Data represent the mean of eight independent replicates. For each nutrient, harvest and plants organ, values followed by the same lower-case letter among treatments (Control, C1, C2, and $\mathrm{C} 3$, respectively) are not statistically different according to one-way ANOVA with Tukey-Kramer post-hoc test at $p<0.05$. $\mathrm{T}_{\mathrm{OC}}$ : total organic carbon. $\mathrm{T}_{\mathrm{N}}$ : total nitrogen. 


\section{Discussion}

In Exp. No. 1, AL compost was evaluated as a potential organic fertiliser during pepper growth ( $C$ treatment), being compared to a standard nutrient solution (NS treatment). The physiological parameters analysed demonstrated that $C$ treated plants did not grow properly since AL compost did not cover their nutritional requirements, especially the nitrogen demand. Although total nitrogen concentration added in C and NS treatments was similar, AL compost nitrogen was predominantly organic and not easily available for pepper roots. In fact, four months was not enough time for the organic nitrogen mineralization in the pots used.
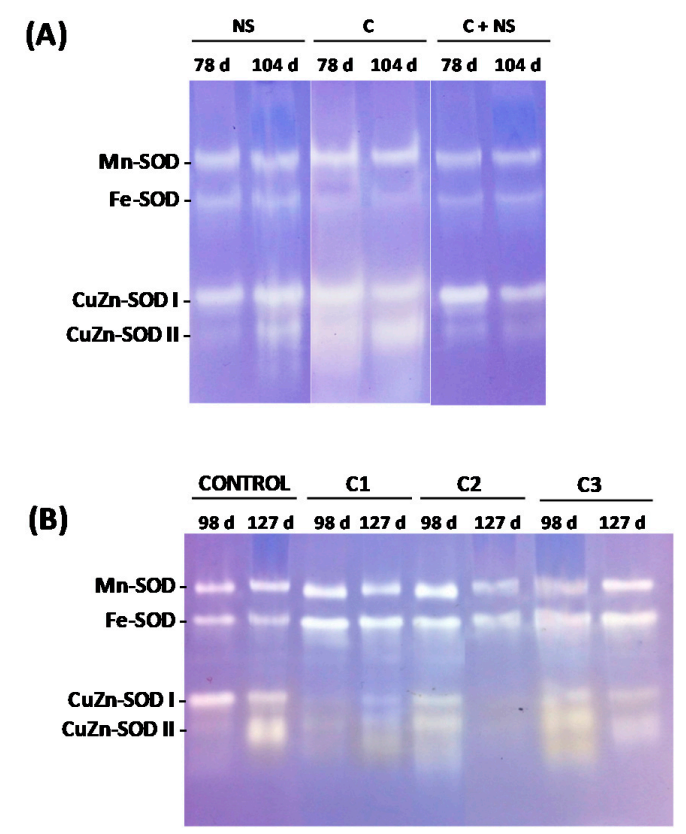

Figure 1. Profiles of the SOD isozymes from pepper leaves (Mn-SOD, Fe-SOD, CuZn-SOD I and CuZn-SOD II) obtained after treatments under different AL compost conditions. Proteins (50 $\mu \mathrm{g}$ per well) were loaded, separated by native-PAGE (10\% acrylamide), and stained by the NBT photochemical method. (A) Exp. No. 1; NS, plants grown with full nutrient solution; C, plants only grown with compost; $\mathrm{C}+\mathrm{NS}$, plants grown with compost and complemented with full nutrient solution. (B) Exp. No. 2; Control, plants grown with full nutrient solution; C1, C2, and C3, plants grown with $8 \%, 17 \%$, and $33 \%(v / v)$ compost, respectively, and supplemented with $\mathrm{NO}_{3}{ }^{-} 14.92 \mathrm{mM}$.

Table 6. Catalase activity and lipid peroxidation determined in pepper leaves of Exp. No. 2 according to treatments assayed. Data were collected from the onset of flowering (98 days) until fruit harvesting (127 days). Control, plants grown with full nutrient solution; $\mathrm{C} 1, \mathrm{C} 2$, and $\mathrm{C} 3$, plants grown with $8 \%$, $17 \%$, and $33 \%(v / v)$ compost, respectively, and supplemented with $\mathrm{NO}_{3}{ }^{-} 14.92 \mathrm{mM}$.

\begin{tabular}{|c|c|c|c|}
\hline Exp. No. 2 Harvest & Treatments & $\begin{array}{l}\text { Catalase Activity ( } \mu \text { mol } \mathrm{H}_{2} \mathrm{O}_{2} \\
\min ^{-1} \mathrm{mg}^{-1} \text { Protein) }\end{array}$ & $\begin{array}{l}\text { Lipid Peroxidation } \\
\left(\mu \mathrm{M} \text { MDA } \mathrm{g}^{-1} \mathrm{FW}\right)\end{array}$ \\
\hline \multirow{4}{*}{98 days } & Control & $39.65 \mathrm{a}$ & $0.33 \mathrm{a}$ \\
\hline & $\mathrm{C} 1$ & $31.20 \mathrm{a}$ & $0.35 \mathrm{a}$ \\
\hline & C2 & $43.37 b$ & $0.41 \mathrm{a}$ \\
\hline & $\mathrm{C} 3$ & $73.96 \mathrm{c}$ & $0.47 \mathrm{a}$ \\
\hline \multirow{4}{*}{127 days } & Control & $68.34 \mathrm{~b}$ & $0.34 \mathrm{a}$ \\
\hline & $\mathrm{C} 1$ & $47.35 \mathrm{a}$ & $0.32 \mathrm{a}$ \\
\hline & C2 & $69.57 \mathrm{~b}$ & $0.38 \mathrm{a}$ \\
\hline & C3 & $71.26 \mathrm{c}$ & $0.41 \mathrm{a}$ \\
\hline
\end{tabular}

Note: Data represent the mean of eight independent replicates. For each column, values followed by the same lower-case letter among treatments are not statistically different according to one-way ANOVA with Tukey-Kramer post-hoc test at $p<0.05$. 
According to these facts, the agronomic effectiveness of AL compost as an organic fertiliser would be dependent on an easily available nitrogen supplementation. When this happened $(C+N S$ treatment), the organic matter of the AL compost improved the growth and the physiological development of pepper plants, as well as the fruit yields, compared to those obtained using only the standard nutrient solution (NS treatment). This effect was especially notable when administration of AL compost doses was more properly applied and complemented with adequate $\mathrm{N}$ amount, as shown by the results of Exp. No. 2. The beneficial effect of AL compost supplemented with nitrate is well documented. Sewage sludge composts with half-strange Hoagland mineral solution increased pepper (Piquillo variety) biomass and yield production among doses, being maximal when $45 \%(w / w)$ of compost was applied [34]. In addition, nitrate-supplemented compost improved strawberry yield under greenhouse conditions [35]. Biowaste vermicompost with nitrate increased the number of pepper fruits per plant and pepper biomass by $17 \%$ and $45 \%$, respectively [36].

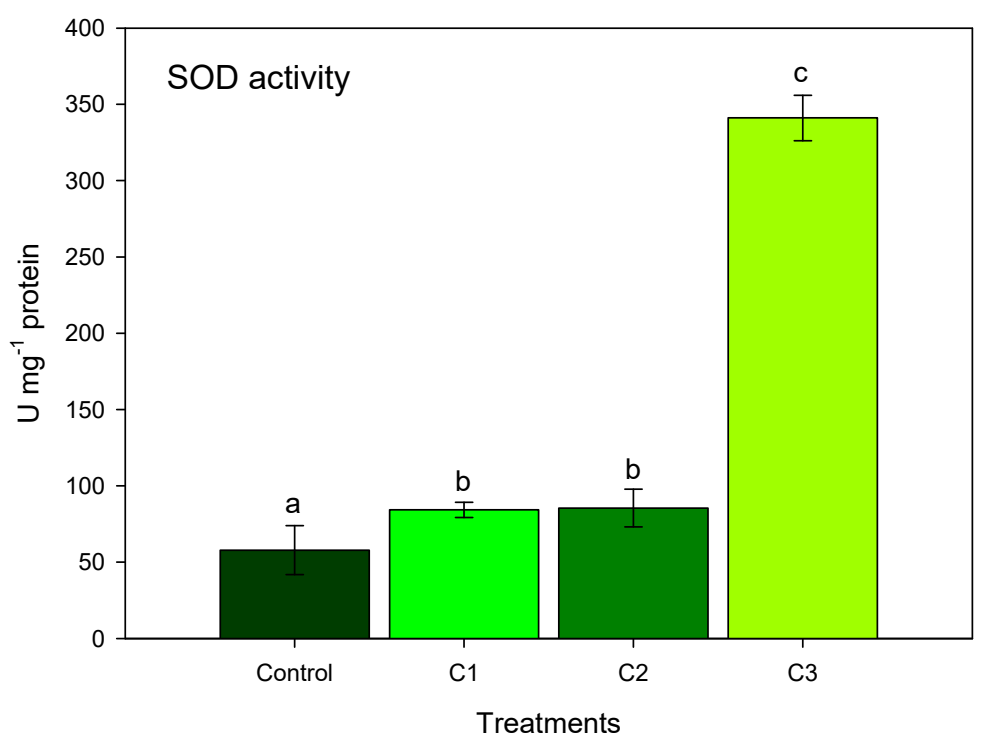

Figure 2. Total superoxide dismutase (SOD) activity in the different treatments of Exp. No. 2. Data were obtained from pepper leaves at the first harvest (98 days). Data represent the mean of eight independent replicates and the same lower-case letter among treatments indicates that they are not statistically different according to one-way ANOVA with Tukey-Kramer post-hoc test at $p<0.05$. Control, plants grown with full nutrient solution; $\mathrm{C} 1, \mathrm{C} 2$, and $\mathrm{C} 3$, plants grown with $8 \%, 17 \%$, and $33 \%$ $(v / v)$ compost, respectively, and supplemented with $\mathrm{NO}_{3}{ }^{-} 14.92 \mathrm{mM}$.

Nitrogen is the main element in the biosphere but is also less bioavailable [37]. Nitrogen is the key nutrient limitation for plants in agriculture. Since the Haber-Bosch process was developed, nitrogen based-fertilisers have contributed largely to improve food production and agricultural yields. Indeed, they are the most used in agriculture, representing $60-71 \%$ of the world demand for fertilisers for 2015-2019 [2]. Nevertheless, agricultural soils are over-fertilized with mineral nitrogen which produces nutrient overloads and nitrogen pollution [38]. To minimize their abuse in agriculture, compost can be used as an alternative but, unfortunately, total nitrogen in composts is predominantly organic, which means not easily assimilable by plants. It is well known that nitrogen losses occurred during composting by either nitrate lixiviation or ammonia volatilization due to $\mathrm{pH}$ alkalization and high temperatures [39]. Some reports have remarked that nitrogen losses can be close to $60 \%$ or more during the process, especially when using ammonia-rich manure such as those generated from poultry [40]. These reasons explain why nitrogen compost is predominantly organic and the success of agronomic trials using compost as an organic fertiliser could be dependent of either the nitrogen demand by crops or the own nitrogen supplementation. To reduce nitrate fertilization and, hence, its negative impact on the environment when it is over-applied, further research needs to be conducted to achieve 
nitrate supplementation alternatives. Some promising strategies include easy nitrogen sources such as biological nitrogen fixation [41,42] or protein hydrolysates [43], being instrumental in organic farming fertilization, which allows us to mitigate nitrate contamination from agricultural soils.

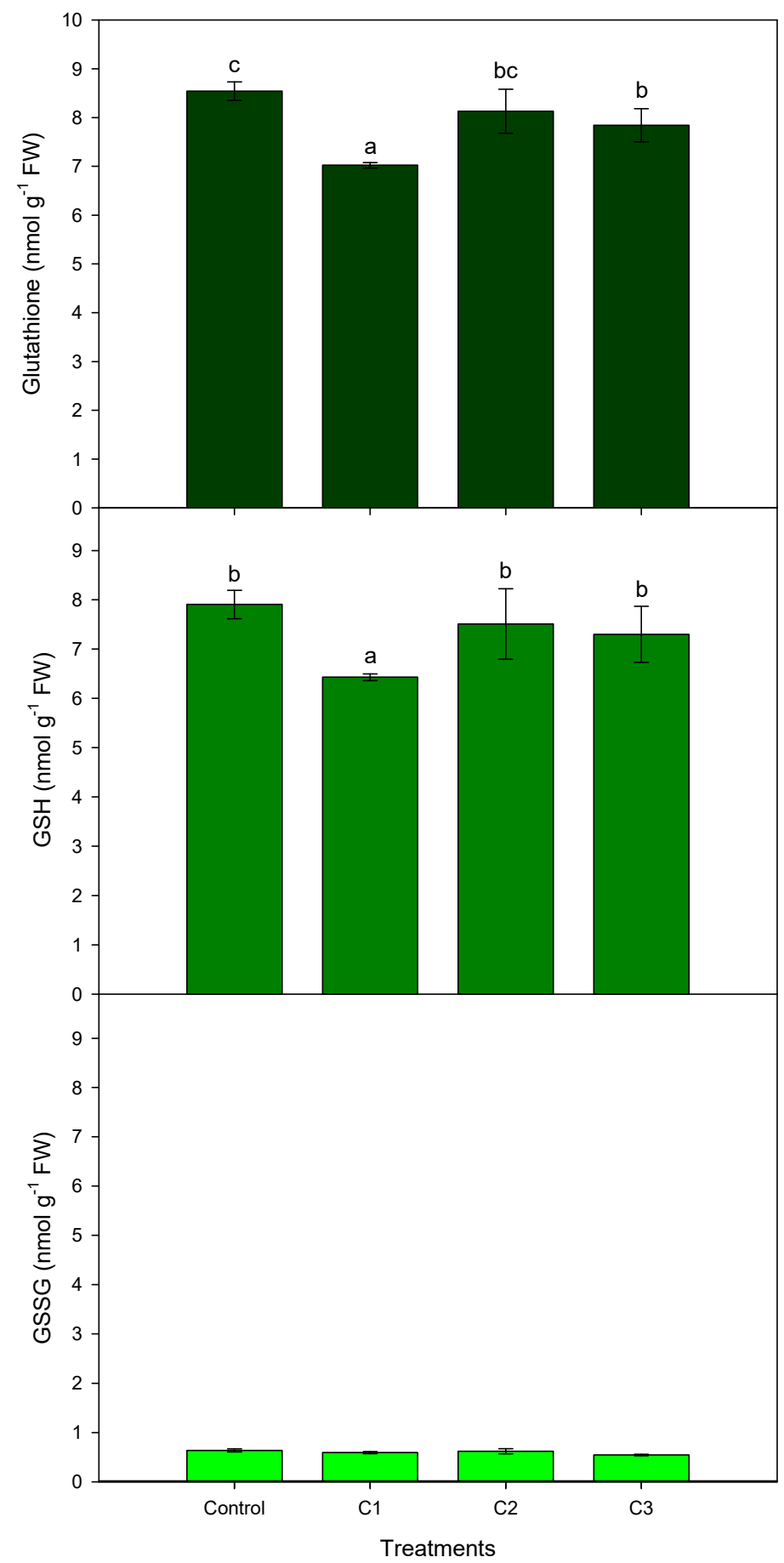

Figure 3. Glutathione, reduced (GSH) and oxidized glutathione (GSSG) in pepper fruits at the second harvest (127 days) of the Exp. No. 2. Data represent the mean of eight independent replicates and the same lower-case letter among treatments indicates that they are not statistically different according to one-way ANOVA with Tukey-Kramer post-hoc test at $p<0.05$. Control, plants grown with full nutrient solution; $\mathrm{C} 1, \mathrm{C} 2$, and $\mathrm{C} 3$, plants grown with $8 \%, 17 \%$, and $33 \%(v / v)$ compost, respectively, and supplemented with $\mathrm{NO}_{3}{ }^{-} 14.92 \mathrm{mM}$. 


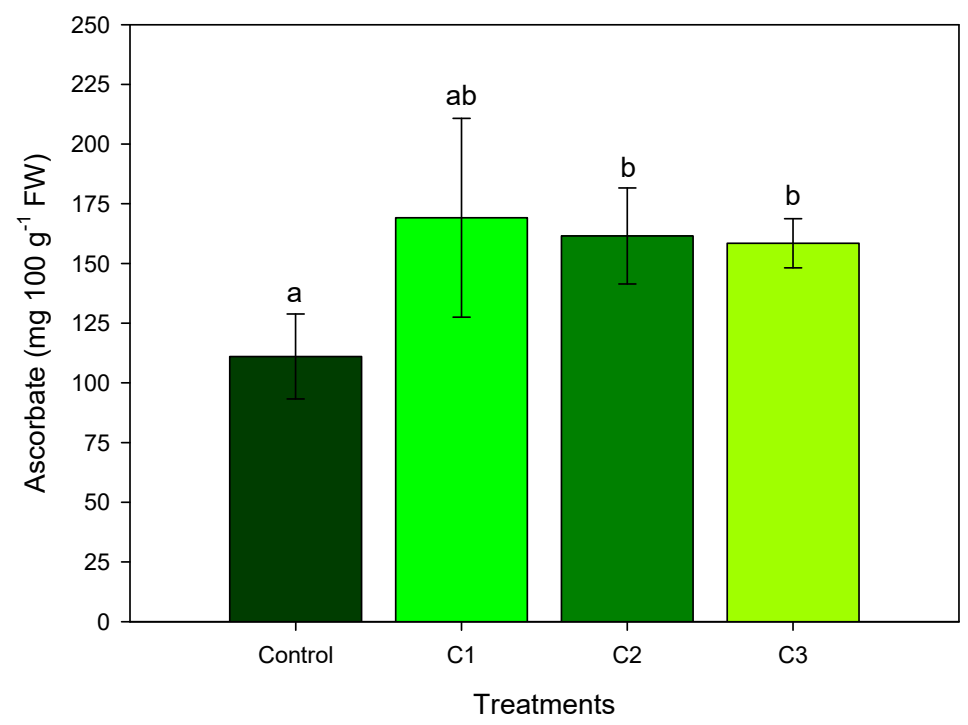

Figure 4. Ascorbate content in pepper fruits at the second harvest (127 days) of the Exp. No. 2. Data represent the mean of eight independent replicates and the same lower-case letter among treatments indicates that they are not statistically different according to one-way ANOVA with Tukey-Kramer post-hoc test at $p<0.05$. Control, plants grown with full nutrient solution; $\mathrm{C} 1, \mathrm{C} 2$, and $\mathrm{C} 3$, plants grown with $8 \%, 17 \%$, and $33 \%(v / v)$ compost, respectively, and supplemented with $\mathrm{NO}_{3}{ }^{-} 14.92 \mathrm{mM}$.

ROS present in plant cells can function as either signalling molecules or toxic by-products of the aerobic metabolism according to their cellular concentrations [20]. It is well documented that certain stress conditions can increase the ROS content such as pathogen infection, high and low temperature, drought and salt stress, heavy metal, atmospheric pollutants and physical and mechanical wounding, among others [19]. This being the case, antioxidants, enzymatic and non-enzymatic either play an important role modulating the levels of ROS in signalling issues or scavenging their deleterious potential when they are over-produced $[19,20]$. Nutrient deficiency also induces ROS signalling, especially during nitrogen, phosphorus and potassium starvation [44]. Additionally, it has been reported that compost can increase the ROS concentration as well as the oxidative metabolism in several plant species when they are subjected to stress conditions such as pathogen wilt diseases, salinity or low temperature [45-47]. Overall, data on the ROS metabolism from our experiments indicate that the cultivation of pepper plants and the quality of fruits could be improved using proper AL compost amounts. Thus, when AL compost was used as a unique substrate, symptoms of oxidative stress seemed to occur. The lower growth of plants was accompanied by lower antioxidative protective systems (ascorbate, ratio GSG/GSSG, and catalase activity). The effect becomes acuter as the experiment is prolonged with lowering of ascorbate content and ratios GSH/GSSG below 1. Conversely, when AL compost is dosed and complemented with the addition of nitrate, growth parameters improved at the same rate as the harvest yield did, and the catalase and ascorbate were enhanced as a consequence of a higher biomass. This behaviour of ascorbate is remarkable since good practises of using AL compost in appropriate conditions may increase the added value of pepper fruits as the content of vitamin $\mathrm{C}$ rises in this reproductive organ destined to human consumption. These data on antioxidative parameters, together with the profile of lipid peroxidation which increased at the same rate as the AL compost levels did, and also pepper development and yield, lead us to think that, possibly the most adequate concentration of compost is that from treatment C3.

Although the effect of compost in the plant oxidative metabolism is well documented, the intimate mechanism involved remains unknown. Probably, the pattern of antioxidants observed in pepper tissues shown in our experiments could be related to some organic fractions already present in the compost, especially those with an important tannin or polyphenol content [48], such as humic 
substances. Mature composts should contain an important humic substances concentration, especially AL composts [12,49]. In addition, humic substances display an important content of stable organic free radicals due to their semiquinone moieties [48]. Indeed, it has been recently reviewed that the ROS-signalling pathway is involved in the beneficial effect of humic substances in plants grown under different conditions [50].

\section{Conclusions}

To conclude, our findings demonstrate that the effectiveness of agronomic trials using AL compost as an organic fertiliser is dependent on the crop nitrogen demand as well as on an easily assimilable nitrogen supplementation. Nitrogen was the key nutrient limitation in pepper growth under greenhouse conditions. The total nitrogen of AL compost used in this study was predominately organic and did not cover the nutritional requirements of the plants. When it was supplemented with nitrate, a remarkable increase in fruit yield and plant development was registered, being especially notable within AL compost doses used. On the other hand, pepper growth without nitrate showed a nitrogen deficiency, increasing the oxidative stress, being the ROS metabolism an effective indicator. This increase of the ROS metabolism was perhaps related to humic fraction of AL compost. Finally, AL compost supplemented with nitrate enhanced ascorbate content in fruits, which can contribute to use this model in the improvement of the quality of pepper fruits.

Author Contributions: G.T., S.G.-G., C.R., E.J.B. and J.M.P. conceived and designed the experiments; G.T., S.G.-G. and C.R. performed the experiments; G.T., S.G.-G. and J.M.P. analysed the data; E.J.B. and J.M.P. contributed with reagents/materials/analysis tools; and G.T. and J.M.P. wrote the paper.

Acknowledgments: G. Tortosa thanks D. Francis Lewis for the improvement of the written English and the local farmer J. González for providing the AL compost used in this study. This work was supported by the ERDF-cofinanced projects AGL2011-26044 and AGL2015-65104-P from the MINECO and P12-AGR1968 from Junta de Andalucía (Spain). Support by Junta de Andalucía to Research Group BIO-275 is also acknowledged. The authors also acknowledge the Scientific Instrumentation Service from the Estación Experimental del Zaidín for antioxidant analysis.

Conflicts of Interest: The authors declare no conflict of interest.

\section{References}

1. White, P.J.; Brown, P.H. Plant nutrition for sustainable development and global health. Ann. Bot. 2010, 105, 1073-1080. [CrossRef] [PubMed]

2. Food and Agriculture Organization of the United Nations (FAO). World Fertiliser Trends and Outlook to 2019 (Summary Report). 2016. Available online: http://www.fao.org/3/a-i5627e.pdf (accessed on 15 November 2017).

3. European Commission. Implementation of Council Directive 91/676/EEC Concerning the Protection of Waters against Pollution Caused by Nitrates from Agricultural Sources; Official Publications of the European Communities, 2002; Available online: http:/ / ec.europa.eu/environment/water/water-nitrates/pdf/91_ 676_eec_en.pdf (accessed on 15 November 2017).

4. Smith, P.; Martino, D.; Cai, Z.; Gwary, D.; Janzen, H.; Kumar, P.; McCarl, B.; Ogle, S.; O’Mara, F.; Rice, C.; et al. Greenhouse gas mitigation in agriculture. Phil. Trans. R. Soc. B 2008, 363, 789-813. [CrossRef] [PubMed]

5. Tortosa, G.; Correa, D.; Sánchez-Raya, A.J.; Delgado, A.; Sánchez-Monedero, M.A.; Bedmar, E.J. Effects of nitrate contamination and seasonal variation on the denitrification and greenhouse gas production in La Rocina Stream (Doñana National Park, SW Spain). Ecol. Eng. 2011, 37, 539-548. [CrossRef]

6. Cayuela, M.L.; Aguilera, E.; Sanz-Cobena, A.; Adams, D.C.; Abalos, D.; Barton, L.; Ryals, R.; Silver, W.L.; Alfaro, M.A.; Pappa, V.A.; et al. Direct nitrous oxide emissions in Mediterranean climate cropping systems: Emission factors based on a meta-analysis of available measurement data. Agric. Ecosyst. Environ. 2017, 238, 25-35. [CrossRef]

7. Food and Agriculture Organization of the United Nations (FAO). Status of the World's Soil Resources Technical Summary; Food and Agriculture Organization of the United Nations: Rome, Italy, 2015; ISBN 978-92-5-108960-6. 
8. Minasny, B.; Malone, B.P.; McBratney, A.B.; Angers, D.A.; Arrouays, D.; Chambers, A.; Chaplot, V.; Chen, Z.S.; Cheng, K.; Das, B.S.; et al. Soil carbon 4 per mille. Geoderma 2017, 292, 59-86. [CrossRef]

9. Alburquerque, J.A.; Gonzálvez, J.; García, D.; Cegarra, J. Agrochemical characterisation of "alperujo", a solid by-product of the two-phase centrifugation method for olive oil extraction. Bioresour. Technol. 2004, 91, 195-200. [CrossRef]

10. Alburquerque, J.A.; Gonzálvez, J.; Tortosa, G.; Baddi, G.A.; Cegarra, J. Evaluation of “alperujo” composting based on organic matter degradation, humification and compost quality. Biodegradation 2009, 20, 257-270. [CrossRef] [PubMed]

11. Tortosa, G.; Alburquerque, J.A.; Ait Baddi, G.; Cegarra, J. The production of commercial organic amendments and fertilisers by composting of two-phase olive mill waste ("alperujo"). J. Clean. Prod. 2012, 26, 48-55. [CrossRef]

12. Tortosa, G.; Alburquerque, J.A.; Bedmar, E.J.; Ait Baddi, G.; Cegarra, J. Strategies to produce commercial liquid organic fertilisers from "alperujo" composts. J. Clean. Prod. 2014, 82, 37-44. [CrossRef]

13. Stevenson, F.J. Humus Chemistry: Genesis, Composition, Reactions, 2nd ed.; John Wiley \& Sons, Inc.: Hoboken, NJ, USA, 1994; ISBN 978-0-471-59474-1.

14. Govindarajan, V.S.; Salzer, U.J. Capsicum production, technology, chemistry, and quality part 1: History, botany, cultivation, and primary processing. Crit. Rev. Food Sci. Nutr. 1985, 22, 109-176. [CrossRef] [PubMed]

15. FAO-STAT. Food and Agriculture Organization of the United Nations (FAO). 2017. Available online: http: / / www.fao.org/faostat (accessed on 15 November 2017).

16. Senesi, N. Composted Materials as organic fertilisers. Sci. Total Environ. 1985, 81/82, 521-542. [CrossRef]

17. Quilty, J.R.; Cattle, S.R. Use and understanding of organic amendments in Australian agriculture: A review. Soil Res. 2011, 49, 1-26. [CrossRef]

18. Martínez-Blanco, J.; Lazcano, C.; Christensen, T.H.; Muñoz, P.; Rieradevall, J.; Møller, J.; Antón, A.; Boldrin, A. Compost benefits for agriculture evaluated by life cycle assessment. A review. Agron. Sustain. Dev. 2013, 33, 721-732. [CrossRef]

19. Del Río, L.A. ROS and RNS in plant physiology: An overview. J. Exp. Bot. 2015, 66, 2827-2837. [CrossRef] [PubMed]

20. Mittler, R. ROS Are Good. Trends Plant Sci. 2017, 22, 11-19. [CrossRef] [PubMed]

21. Halliwell, B. The antioxidant paradox: Less paradoxical now? Br. J. Clin. Pharmacol. 2012, 75, 637-644. [CrossRef] [PubMed]

22. Palma, J.M.; Sevilla, F.; Jiménez, A.; del Río, L.A.; Corpas, F.J.; Álvarez de Morales, P.; Camejo, D.M. Physiology of pepper fruit and the metabolism of antioxidants: Chloroplasts, mitochondria and peroxisomes. Ann. Bot. 2015, 116, 627-636. [CrossRef] [PubMed]

23. Palma, J.M.; Corpas, F.J.; del Río, L.A. Plant vitamin antioxidants and their influence on the human diet. In Fruit and vegetable consumption and health; Papareschi, A., Eppolito, H., Eds.; Nova Science Publishers Inc.: New York, NY, USA, 2009; pp. 127-138.

24. Howard, L.R.; Talcott, S.T.; Brenes, C.H.; Villalon, B. Changes in Phytochemical and Antioxidant Activity of Selected Pepper Cultivars (Capsicum Species) As Influenced by Maturity. J. Agric. Food Chem. 2000, 48, 1713-1720. [CrossRef] [PubMed]

25. Chowdhury, A.K.M.M.B.; Akratos, C.S.; Vayenas, D.V.; Pavlou, S. Olive mill waste composting: A review. Int. Biodeterior. Biodegrad. 2013, 85, 108-119. [CrossRef]

26. Del Río, L.A.; Sandalio, L.M.; Yáñez, J.; Gómez, M. Induction of a manganese-containing superoxide dismutase in leaves of Pisum sativum L. by high nutrient levels of zinc and manganese. J. Inorg. Biochem. 1985, 24, 25-34. [CrossRef]

27. Bradford, M.M. A rapid and sensitive method for the quantitation of microgram quantities of protein utilizing the principle of protein-dye binding. Anal. Biochem. 1986, 72, 248-254. [CrossRef]

28. Aebi, H. Catalase in vitro. Methods Enzymol. 1984, 105, 121-126. [PubMed]

29. McCord, J.M.; Fridovich, I. Superoxide dismutase: An enzymic function for erythrocuprein. J. Biol. Chem. 1969, 244, 6049-6055. [PubMed]

30. Beauchamp, C.O.; Fridovich, I. Superoxide dismutase: Improved assays and an assay applicable to acrylamide gels. Anal. Biochem. 1971, 44, 276-287. [CrossRef]

31. Buege, J.A.; Aust, S.D. Microsomal lipid peroxidation. Methods Enzymol. 1978, 52, 302-310. [PubMed] 
32. Rodríguez-Ruiz, M.; Mateos, R.M.; Codesido, V.; Corpas, F.J.; Palma, J.M. Characterization of the galactono-1,4-lactone dehydrogenase from pepper fruits and its modulation in the ascorbate biosynthesis. Role of nitric oxide. Redox Biol. 2017, 12, 171-181. [CrossRef] [PubMed]

33. Airaki, M.; Leterrier, M.; Mateos, R.M.; Valderrama, R.; Chaki, M.; Barroso, J.B.; Del Río, L.A.; Palma, J.M.; Corpas, F.J. Metabolism of reactive oxygen species and reactive nitrogen species in pepper (Capsicum annuum L.) plants under low temperature stress. Plant Cell Environ. 2011, 35, 281-295. [CrossRef] [PubMed]

34. Pascual, I.; Azcona, I.; Guirreolea, J.A.; Morales, F.; Corpas, F.J.; Palma, J.M.; Rellán-Álvarez, R.; Sánchez-Díaz, M.J. Growth, Yield, and Fruit Quality of Pepper Plants Amended with Two Sanitized Sewage Sludges. J. Agric. Food Chem. 2010, 58, 6951-6959. [CrossRef] [PubMed]

35. Wang, S.Y.; Lin, H.S. Compost as a Soil Supplement Increases the Level of Antioxidant Compounds and Oxygen Radical Absorbance Capacity in Strawberries. J. Agric. Food Chem. 2003, 51, 6844-6850. [CrossRef] [PubMed]

36. Arancon, N.Q.; Edwards, C.A.; Atiyeh, R.; Metzger, J.D. Effects of vermicomposts produced from food waste on the growth and yields of greenhouse peppers. Bioresour. Technol. 2004, 93, 139-144. [CrossRef] [PubMed]

37. Galloway, J.N.; Aber, J.D.; Erisman, J.W.; Seitzinger, S.P.; Howarth, R.W.; Cowling, E.B.; Cosby, B.J. The Nitrogen Cascade. BioScience 2003, 53, 341-356. [CrossRef]

38. Good, A.G.; Beatty, P.H. Fertilizing Nature: A Tragedy of Excess in the Commons. PLoS Biol. 2011, 9, e1001124. [CrossRef] [PubMed]

39. Martins, O.; Dewes, T. Loss of Nitrogenous Compounds during Composting of Animal Wastes. Bioresour. Technol. 1992, 42, 103-111. [CrossRef]

40. Tiquia, S.M.; Tam, N.F.Y. Fate of nitrogen during composting of chicken litter. Environ. Pollut. 2000, 110, 535-541. [CrossRef]

41. Herridge, D.F.; Peoples, M.B.; Boddey, R.M. Global inputs of biological nitrogen fixation in agricultural systems. Plant Soil. 2008, 311, 1-18. [CrossRef]

42. Bhat, T.A.; Ahmad, L.; Ganai, M.A.; Haq, S.U.; Khan, O.A. Nitrogen Fixing Biofertilisers; Mechanism and Growth Promotion: A Review. J. Pure Appl. Microbiol. 2015, 9, 1675-1690.

43. Adamczyk, B.; Smolander, A.; Kitunen, V.; Godlewski, M. Proteins as nitrogen source for plants. A short story about exudation of proteases by plant roots. Plant Signal. Behav. 2010, 5, 817-819. [CrossRef]

44. Shin, R.; Berg, R.H.; Schachtman, D.P. Reactive Oxygen Species and Root Hairs in Arabidopsis Root Response to Nitrogen, Phosphorus and Potassium Deficiency. Plant Cell Physiol. 2005, 46, 1350-1357. [CrossRef] [PubMed]

45. Tartoura, K.A.H.; Youssef, S.A. Stimulation of ROS-scavenging systems in squash (Cucurbita pepo L.) plants by compost supplementation under normal and low temperature conditions. Sci. Hortic. 2011, 130, 862-868. [CrossRef]

46. Youssef, S.A.; Tartoura, K.A.H. Compost enhances plant resistance against the bacterial wilt pathogen Ralstonia solanacearum via up-regulation of ascorbate-glutathione redox cycle. Eur. J. Plant Pathol. 2013, 137, 821-834. [CrossRef]

47. Tartoura, K.A.H.; Youssef, S.A.; Tartoura, E.A.A. Compost alleviates the negative effects of salinity via up-regulation of antioxidants in Solanum lycopersicum L. plants. Plant Growth Regul. 2014, 74, 299-310. [CrossRef]

48. Rimmer, D.L. Free radicals, antioxidants, and soil organic matter recalcitrance. Eur. J. Soil Sci. 2006, 57, 91-94. [CrossRef]

49. Masmoudi, S.; Jarboui, R.; Feki, H.E.; Gea, T.; Medhioub, K.; Ammar, E. Characterization of olive mill wastes composts and their humic acids: Stability assessment within different particle size fractions. Environ. Technol. 2013, 34, 787-797. [CrossRef] [PubMed]

50. Calderín-García, A.; Olaetxea, M.; Santos, L.A.; Mora, V.; Baigorri, R.; Fuentes, M.; Zamarreño, A.M.; Louro-Berbara, R.L.; Garcia-Mina, J.M. Involvement of Hormone- and ROS-Signaling Pathways in the Beneficial Action of Humic Substances on Plants Growing under Normal and Stressing Conditions. BioMed Res. Int. 2016, 3747501. [CrossRef]

(C) 2018 by the authors. Licensee MDPI, Basel, Switzerland. This article is an open access article distributed under the terms and conditions of the Creative Commons Attribution (CC BY) license (http://creativecommons.org/licenses/by/4.0/). 